\title{
PERBANDINGAN KINERJA KEUANGAN PERUSAHAAN TELEKOMUNIKASI YANG TERDAFTAR DI BURSA EFEK INDONESIA PERIODE 2008 - 2017 (STUDI KASUS PADA PT. TELEKOMUNIKASI INDONESIA TBK, PT. INDOSAT TBK, DAN PT. XL AXIATA TBK)
}

\author{
Fensca Fenolisa Lahallo \\ Universitas Victory Sorong, Papua Barat. \\ ekalahallo120@gmail.com
}

\begin{abstract}
Comparison of Financial Performance of Telecommunications Companies Listed on the Indonesia Stock Exchange Period 2008 - 2017 (Case Study at PT. Telekomunikasi Indonesia Tbk, PT. Indosat Tbk, and PT. Xl Axiata Tbk). The purpose of this study is to compare the financial performance of PT. Telekomunikasi Indonesia Tbk, PT. Indosat Tbk, and PT. XL Axiata Tbk Period 2008 - 2017. This type of research is comparative research. The population used is the telecommunications service companies listed as public companies (issued) on the Indonesia Stock Exchange (IDX) for the period 2008 - 2017 and the sampling technique used is purposive sampling based on certain criteria and determined by companies that included into the classter 3 of the largest and best telecommunication companies in the period 2008 - 2017 and has published the annual financial statements in the year 2008 -2017. Thus the sample in this study is PT. Telekomunikasi Indonesia Tbk, PT Indosat Tbk and PT. PT.XL Axiata Tbk. Data analysis technique used was quantitative descriptive analysis and comparison test used statistical analysis (parametric statistical difference test). The results showed that from the results of different test using One-way ANOVA obtained results there are significant differences between financial performance of PT. Telekomunikasi Indonesia Tbk, PT. Indosat Tbk and PT. XL Axiata Tbk seen from liquidity ratios, solvency ratios, activity ratios and profitability ratios.
\end{abstract}

Keyword: Financial Performance, Liquidity, Solvency, Activity and Profitability

\begin{abstract}
Abstrak: Perbandingan Kinerja Keuangan Perusahaan Telekomunikasi Yang Terdaftar di Bursa Efek Indonesia Periode 2008 - 2017(Studi Kasus Pada PT. Telekomunikasi Indonesia Tbk, PT. Indosat Tbk, Dan PT. XI Axiata Tbk). Tujuan dilakukannya penelitian ini yaitu untuk membandingkan kinerja keuangan PT. Telekomunikasi Indonesia Tbk, PT. Indosat Tbk, dan PT.XL Axiata Tbk Periode 2008 - 2017. Jenis penelitian ini adalah penelitian komparatif. Populasi yang digunakan adalah perusahaan jasa telekomunikasi yang terdaftar sebagai perusahaan publik (emiten) di Bursa Efek Indonesia (BEI) periode 2008 - 2017 serta teknik sampling yang digunakan yaitu purposive sampling berdasarkan kriteria tertentu dan ditentukan perusahaan yang masuk dalam kategori 3 perusahaan telekomunikasi terbesar dan terbaik dalam periode 2008 - 2017 serta telah menerbitkan laporan keuangan tahunan pada tahun 2008 -2017. Dengan demikian sampel dalam penelitian ini adalah PT. Telekomunikasi Indonesia Tbk, PT Indosat Tbk dan PT.XL Axiata Tbk. Teknik analisis data yang digunakan adalah analisis deskriptif kuantitatif dan untuk menguji perbandingannya menggunakan analisis statistik (uji beda statistik parametrik). Hasil penelitian menunjukkan bahwa dari hasil uji beda menggunakan One-way ANOVA memperoleh hasil terdapat perbedaan yang signifikan antara kinerja keuangan PT. Telekomunikasi Indonesia Tbk, PT. Indosat Tbk dan PT. PT.XL Axiata Tbk dilihat dari rasio likuiditas, rasio solvabilitas, rasio aktivitas dan rasio profitabilitas.
\end{abstract}

Kata Kunci: Kinerja Keuangan, Likuiditas, Solvabilitas, Aktivitas dan Profitabilitas 


\section{PENDAHULUAN}

Salah satu tolak ukur keberhasilan atau kegagalan suatu perusahaan dapat dilihat dari kinerja keuangan perusahaan tersebut. Kinerja keuangan merupakan gambaran dari pencapaian keberhasilan kondisi keuangan perusahaan pada periode tertentu yang dapat membantu para investor untuk mengambil suatu keputusan dalam berinvestasi pada suatu perusahaan. Kinerja keuangan suatu perusahaan dapat dinilai dengan beberapa analisis yaitu, analisis rasio likuiditas, rasio solvabilitas, rasio aktivitas dan rasio profitabilitas. Rasio likuiditas berguna untuk mengukur kemampuan likuiditas jangka pendek perusahaan dengan melihat aktiva lancar perusahaan terhadap hutang lancarnya. Rasio solvabilitas perusahaan mengukur kemampuan perusahaan dalam memenuhi kewajiban-kewajiban jangka panjangnya. Rasio aktivitas berguna untuk mengukur keefektifan perusahaan menggunakan assetnya, sedangkan Rasio profitabilitas perusahaan mengukur kemampuan perusahaan menghasilkan keuntungan pada tingkat periode tertentu dan juga memberikan gambaran tentang tingkat efektifitas manajemen dalam melaksanakan kegiatan operasinya.

Di Indonesia terdapat banyak sekali perusahaan-perusahaan telekomunikasi yang telah go public dan memiliki laporan keuangan yang berfluktuasi seperti PT. Bakrie Telekom Tbk, PT.XL Axiata Tbk, PT. Telekomunikasi Indonesia Tbk, PT. Indosat Tbk, PT. Smartfren Telekom Tbk dan lainnya. PT. Telekomunikasi Indonesia Tbk, PT.Indosat Tbk, dan PT.XL Axiata Tbk merupakan perusahaan telekomunikasi terkemuka di Indonesia dan menjadi perusahaan go public yang telah terdaftar di BEI dan telah melaporkan laporan keuangannya secara rutin, serta memiliki kinerja keuangan perusahaan yang berfluktuasi. PT. Telekomunikasi Indonesia Tbk, PT. Indosat Tbk, dan PT.XL Axiata Tbk adalah perusahaan telekomunikasi yang memegang pangsa pasar sekarang, perusahaan tersebut perlu melakukan penilaian kinerja keuangannya.

Banyak penelitian terdahulu yang telah dilakukan untuk menganalisis perbandingan antara kinerja keuangan perusahaan telekomunikasi di Indonesia, misalnya : (1) Agastha dan Budiyanto (2012), hasil penelitiannya menunjukkan bahwa analisis rasio keuangan dan analisis trend, PT.Telkom Indonesia mempunyai kinerja keuangan yang lebih bagus daripada PT. Indosat Tbk. (2) Ulum, Mardani , dan Wahono (2016), hasil penelitiannya menunjukkan bahwa nilai ratarata current ratio, debt to equity ratio, return on equity, return on asset, net profit margin, dan total asset turnover nilai rata-rata PT Telekomunikasi Indonesia Tbk lebih baik dari pada PT Indosat Tbk, sedangkan nilai rata-rata economic value added (EVA) PT Telekomunikasi Indonesia Tbk lebih baik dari pada PT Indosat Tbk. (3) Supit (2013), dalam penelitiannya menunjukkan hasil penelitian yang berbeda dari kedua penelitian terdahulu sebelumnya yaitu tidak terdapat perbedaan antara kinerja keuangan pada PT. Telkom dan PT. Indosat.(4) Kindangen (2016) menyatakan bahwa nilai Current Ratio (CR), Quick Ratio (QR), Debt to Asset Ratio (DAR), dan Return On Asset (ROA), menunjukkan terdapat perbedaan yang signifikan antara kinerja keuangan PT. Telekomunikasi Indonesia Tbk dengan PT. XL Axiata Tbk Periode 2011-2014. Untuk nilai Debt to Equity Ratio (DER) dan Return On Equity Ratio (ROE), hasil perhitungan menunjukan tidak terdapat perbedaan yang signifikan antara kinerja keuangan PT. Telekomunikasi Indonesia Tbk dengan PT. XL Axiata Tbk Periode 20112014. (5) Irene (2013), hasil penelitian menunjukkan tidak terdapat perbedaan yang signifikan terhadap kinerja keuangan antara PT XL Axiata Tbk dan PT Indosat Tbk.

Hasil penelitian oleh Agastha, Budiyanto (2012) dan Ulum, dkk (2016) yang dilakukan pada objek yang sama yaitu perbandingan kinerja keuangan PT. Telekomunikasi Indonesia Tbk. dan PT. Indosat Tbk pada periode penelitian yang hampir sama menunjukkan hasil penelitian yang saling bertolak belakang, sedangkan penelitian yang dilakukan oleh Yolanda menunjukkan bahwa tidak ada perbedaan 
kinerja keuangan antara PT. Telekomunikasi Indonesia Tbk. dan PT. Indosat Tbk. Hasil penelitian yang membandingkan kinerja keuangan PT. Telekomunikasi Indonesia Tbk dan PT. XL Axiata Tbk yang dilakukan oleh Claudia Friska Kindangen menunjukkan bahwa kinerja PT. Telekomunikasi Indonesia masih lebih baik dari PT. XL Axiata Tbk, sedangkan perbandingan kinerja keuangan antara PT. Indosat Tbk dengan PT. XL Axiata Tbk yang dilakukan oleh Yolanda menunjukkan tidak terdapat perbedaan yang signifikan.

Berdasarkan latar belakang yang telah dikemukakan di atas, maka rumusan masalah dalam penelitian ini adalah : (1) Bagaimana kinerja keuangan PT. Telekomunikasi Indonesia Tbk, PT. Indosat Tbk, dan PT.XL Axiata Tbk Periode 2008 - 2017? (2) Bagaiamana perbandingan kinerja keuangan PT. Telekomunikasi Indonesia Tbk, PT. Indosat Tbk, dan PT.XL Axiata Tbk Periode 2008 - 2017? Penelitian ini bertujuan untuk mengetahui perbandingankinerja keuangan PT. Telekomunikasi Indonesia Tbk, PT. Indosat Tbk, dan PT.XL Axiata Tbk Periode 2008 - 2017 dan untuk membandingkan kinerja keuangan ketiga perusahaan dengan menggunakan analisis rasio keuangan dan dilakukan uji bedanya dengan menggunakan uji statistik parametrik.

\section{KAJIAN PUSTAKA \\ Kinerja Keuangan}

Kinerja keuangan merupakan prestasi yang dicapai oleh perusahaan pada saat tertentu dengan menggunakan perhitungan berdasarkan tolak ukur analisis rasio yang didasarkan pada laporan keuangan. Pengukuran kinerja sangat penting dilakukan dengan tujuannya untuk menilai efektivitas dan efesiensi perusahaan. Kinerja keuangan merupakan hasil nyata yang dicapai suatu badan usaha dalam suatu periode tertentu yang dapat mencerminkan tingkat kesehatan keuangan badan usaha tertentu dan dipergunakan untuk menunjukkan dicapainya hasil yang positif. Kinerja keuangan suatu perusahaan dapat dilihat dan diukur dengan cara menganalisis laporan keuangan yang tersedia. Melalui analisis laporan keuangan, keadaan dan perkembangan finansial perusahaan serta hasil-hasil yang telah dicapai perusahaan dapat diketahui, baik di waktu lampau maupun di waktu yang sedang berjalan sehubungan dengan pemilihan strategi perusahaan yang akan diterapkan.

\section{Laporan Keuangan}

\section{a. Pengertian Laporan Keuangan}

Laporan keuangan sebagai alat yang sangat penting untuk memperoleh informasi sehubungan dengan adanya keinginan pihak-pihak tertentu yang berkepentingan terhadap laporan keuangan tersebut. Laporan keuangan akan lebih berarti bagi pihakpihak yang berkepentingan apabila dianalisa lebih lanjut, sehingga diperoleh informasi yang dapat mendukung kebijakan yang akan diambil. Menurut Fahmi (2015 : 21) laporan keuangan merupakan suatu informasi yang menggambarkan kondisi keuangan suatu perusahaan, dan lebih jauh informasi tersebut dapat dijadikan sebagai gambaran kinerja keuangan perusahaan tersebut. Adapun jenis laporan keuangan yang lazim dikenal adalah laporan neraca, laporan laba/rugi atau hasil usaha, laporan arus kas, laporan perubahan posisi keuangan. Tujuan laporan keuangan adalah menyediakan informasi yang menyediakan posisi keuangan, kinerja serta perubahan posisi keuangan perusahaan yang bermanfaat bagi sejumlah besar pemakai dalam pengambilan keputusan ekonomi.

\section{b. Analisis Laporan Keuangan}

Sebuah laporan keuangan yang disajikan dan diperlihatkan oleh pihak akuntan, maka selanjutnya menjadi tanggungjawab bagi manajer perusahaan melakukan analisis secara komprehensif dan kritis terhadap seluruh isi dari laporan keuangan tersebut. Dengan analisis secara komprehensif dan kritis tersebut diharapkan diperoleh hasil kesimpulan atau rekomendasi yang maksimal dalam menilai kinerja keuangan suatu perusahaan, termasuk sebagai rekomendasi pendukung base keputusan.

Alat analisis yang digunakan untuk menganalisis laporan keuangan yaitu analisis 
rasio keuangan yang terdiri dari :

\section{Rasio Keuangan}

Rasio keuangan didesain untuk memperlihatkan hubungan atara item-item pada laporan keuangan (neraca dan laporan laba/rugi) diantaranya :

\section{a. Ratio Likuiditas}

Rasio likuiditas adalah rasio yang digunakan untuk mengukur kemampuan perusahaan dalam membayar kewajiban jangka pendek dari perusahaan dengan melihat aktiva lancar perusahaan yang relatif terhadap hutang lancarnya (Hanafi dan Halim, 2014 75). Rasio likuiditas yang digunakan adalah:

\section{1)}

Rasio Lancar (Current Ratio)

Rasio lancar, yaitu rasio yang digunakan untuk mengetahui posisi kas perusahaan dan kemampuan memenuhi kewajiban/hutang jangka pendek. Rasio lancar didapat dari harta lancar dibagi hutang lancar. Harta lancar merupakan pospos yang berumur satu tahun atau kurang, sedangka hutang lancar merupakan kewajiban pembayaran dalam satu tahun (Giri, 2017 : 16). Dalam situasi rasio lancar lebih besar dari satu, maka kemungkinan besar perusahaan akan mampu membayar hutanghutangnya dan sebaliknya. Secara historis, angka 2 : 1 merupakan perbandingan ideal yang minimum, namun perbandingan yang sesungguhnya tergantung pada situasi dan kondisi financial perusahaan.

\section{2) Rasio Cepat (Quick Ratio)}

Quick Ratio, adalah rasio yang digunakan untuk membandingkan hutang lancar perusahaan dengan aktiva/harta lancarnya, yang terdiri dari : kas, surat berharga yang dapat diperjualbelikan, dan piutang dagang. Rasio cepat didapat dari harta lancar dikurangi inventori bagi hutang lancar. Harta lancar merupakan pos-pos yang berumur satu tahun atau kurang, hutang lancar merupakan kewajiban pembayaran dalam satu tahun, sedangkan persediaan terdiri dari alatalat kantor, persediaan bahan baku,persediaan barang dalam proses dan persediaan barang jadi. (Giri, 2017 : 16).

\section{b. Rasio Solvabilitas / Utang.}

Rasio solvabilitas adalah rasio yang digunakan untuk mengukur kemampuan perusahaan dalam melunasi kewajiban jangka panjangnya (Hanafi dan Halim, 2014 - 79). Perusahaan yang tidak solvable adalah perusahaan yang total utangnya lebih besar dibandingkan dengan total asetnya. Rasio yang digunakan untuk mengukur tingkat solvabilitas perusahaan dalam penelitian ini sebagai berikut:

\section{1) Debt to Assets Ratio}

Debt to assets ratio, yaitu rasio yang digunakan untuk mengetahui persentase dari asset total yang dibiayai oleh kreditur, kewajiban-kewajiban, dan hutang-hutang. Rasio ini didapat dari total hutang dibagi total harta. Total hutang adalah jumlah nilai hutang yang dimiliki oleh perusahaan baik hutang jangka pendek maupun hutang jangka panjang. Total harta adalah jumlah kekayaan yang dimiliki oleh perusahaan dan bisa diukur secara jelas (Giri, 2017 : 17).

\section{2) Debt to Equity Ratio}

Rasio ini digunakan untuk mengukur besarnya risiko financial yang dibebankan kepada pemilik modal atau pemegang saham, dimana semakin tinggi nilai rasio ini menunjukkan semakin beresiko bagi para pemegang saham dalam menanggung atau membiayai hutang perusahaan. Rasio hutang terhadap ekuitas diukur berdasarkan formula total hutang dibagi ekuitas.

\section{c. Rasio Aktivitas}

Rasio aktivitas mengukur seberapa efektif perusahaan memanfaatkan semua sumber daya yang ada pada pengendaliannya. Rasio ini digunakan dengan membandingkan penjualan dengan berbagai investasi dalm aktiva sehingga kita dapat mengetahui seberapa lancar jalannya kegiatan operasional perusahaan sehari-hari. Rasio Aktivitas yang mengukur sejauh mana efektifitas penggunaan asset dengan melihat tingkat aktivitas asset (Hanafi dan Halim, 2014 - 76).

\section{Total Assets Turnover}

Total assets turnover disebut juga dengan perputaran total asset. Rasio ini melihat sejauh mana keseluruhan asset yang dimiliki oleh perusahaan terjadi perputaran secara efektif (Fahmi, 2015 : 80). Rasio ini 
digunakan juga untuk mengukur hubungan antara penjualan bersih (net sales) dan ratarata total harta. Rasio ini menunjukkan berapa rupiah penjualan bersih yang dapat dihasilkan oleh setiap rupiah yang diinvestasikan dalam bentuk harta perusahaan. Semakin tinggi nilai rasio perputaran harta, maka semakin diinginkan oleh manajemen, karena menunjukkan tingkat perputaran harta yang semakin cepat dalam perusahaan.

\section{d. Rasio Profitabilitas.}

Rasio profitabilitas akan memberikan gambaran tentang efektivitas manajemen perusahaan dan tingkat efektivitas pengelolaan perusahaan. Rasio profitabilitas yang digunakan dalam penelitian ini adalah:

\section{3) Net Profit Margin}

Rasio net profit margin disebut juga dengan rasio pendapatan terhadap penjualan (Fahmi, 2015 : 81). Rasio ini digunakan untuk membantu manajemen perusahaan dalam memproyeksikan laba bersih berdasarkan perkiraan penjualan, juga dalam melakukan perbandingan antara hasil aktual dalam menjalankan rencana bisnis dengan hasil aktual pada waktu yang lalu, apakah semakin meningkat atau menurun. Semakin tinggi nilai keuntungan bersih dibandingkan dengan penjualan bersih, menunjukkan bahwa kinerja perusahaan semakin baik. Rasio ini diukur dengan formula keuntungan bersih dibagi penjualan bersih kali seratus persen.

\section{2) Return On Assets (ROA)}

Return on assets digunakan untuk mengukur kemampuan perusahaan menciptakan keuntungan dari set-set yang dikendalikan oleh manajemen. Rasio ini juga disebur dengan return on investment (ROI). Rasio ini melihat sejauh mana investasi yang telah ditanamkan mampu memberikan pengembalian keuntungan sesuai yang diharapkan (Fahmi, 2015 : 82).

\section{3) Return On Equity (ROE)}

Return on equity disebut juga dengan

laba atas equity. Rasio ini mengkaji sejauh mana suatu perusahaan mempergunakan sumber daya yang dimiliki untuk mampu memberikan laba atas ekuitas (Fahmi, 2015 : 82). Rasio ini diukur dengan menggunakan formula keuntungan bersih dibagi total ekuitas dikali seratus.

\section{HIPOTESIS}

Ha: Terdapat perbedaan yang signifikan antara kinerja keuangan pada PT. Telekomunikasi Indonesia Tbk, PT Indosat Tbk dan PT. PT.XL Axiata Tbk dilihat dari rasio likuiditas, rasio solvabilitas, rasio aktivitas dan rasio profitabilitas.

H0: Tidak terdapat perbedaan yang signifikan kinerja keuangan pada PT. Telekomunikasi Indonesia Tbk, PT Indosat Tbk dan PT. PT.XL Axiata Tbk dilihat dari rasio likuiditas, rasio solvabilitas, rasio aktivitas dan rasio profitabilitas.

\section{METODE PENELITIAN}

Jenis penelitian ini menggunakan penelitian komparatif. Komparatif adalah suatu penelitian yang bersifat membandingkan (Kindangen, 2016). Populasi dalam penelitian ini perusahaan jasa telekomunikasi yang terdaftar sebagai perusahaan publik (emiten) di Bursa Efek Indonesia (BEI) periode 2008 - 2017. Penentuan sampel dalam penelitian ini adalah dengan menggunakan teknik purposive sampling yaitu teknik penentuan sampel berdasarkan kriteria-kriteria tertentu. Kriteria yang ditentukan adalah perusahaan yang masuk dalam kategori 3 perusahaan telekomunikasi terbesar dan terbaik dalam periode 2008 - 2017 serta telah menerbitkan laporan keuangan tahunan pada tahun 2008 -2017. Dengan demikian sampel dalam penelitian ini adalah PT. Telekomunikasi Indonesia Tbk, PT Indosat Tbk dan PT. PT.XL Axiata Tbk,

Data yang digunakan di dalam penelitian ini adalah data sekunder berupa laporan keuangan PT. Telekomunikasi Indonesia Tbk, PT Indosat Tbk dan PT. PT.XL Axiata Tbk, yaitu Laporan Neraca dan Laporan Laba Rugi masing-masing perusahaan pada Periode 2008 - 2017 yang diakses melalui (http://www.idx.co.id/). Teknik analisis data yang digunakan adalah analisis deskriptif kuantitatif menggunakan analisis statistik (uji beda statistik parametrik). 
Tabel 1. Uji Normalitas

\begin{tabular}{|c|c|c|c|c|c|}
\hline & N & Mean & $\begin{array}{c}\text { Stand. } \\
\text { Deviasi }\end{array}$ & KS-Z & $\begin{array}{c}\text { Asym. } \\
\text { sig }\end{array}$ \\
\hline CR & 30 & 70.335 & 28.667 & 1.095 & 0.182 \\
\hline QR & 30 & 69.157 & 28.219 & 1.139 & 0.150 \\
\hline DAR & 30 & 60.647 & 12.869 & 0.758 & 0.614 \\
\hline DER & 30 & 184.536 & 107.194 & 0.743 & 0.638 \\
\hline TAT & 30 & 0.541 & 0.130 & 0.828 & 0.499 \\
\hline NPM & 30 & 9.790 & 10.685 & 0.791 & 0.559 \\
\hline ROA & 30 & 6.196 & 6.862 & 1.036 & 0.233 \\
\hline ROE & 30 & 12.255 & 13.944 & 0.987 & 0.284 \\
\hline
\end{tabular}

\section{Uji Asumsi Klasik}

Uji asumsi klasik yang digunakan di dalam penelitian ini yaitu menggunakan uji normalitas distribusi dan uji homogenitas.

a. Uji normalitas data menggunakan Kolmogorov-Smirnov. Uji normalitas dilakukan untuk menguji apakah dalam model regresi variabel residual memiliki distribusi normal ataukah tidak (Ghozali, 2016 : 154). Jika angka signifikan Kolmogorov-Smirnov Sig. > 0,05 maka menunjukkan bahwa data berdistibusi normal dan sebaliknya jika angka sgnifikansi Kolmogorov-Smirnov $<0,05$ maka data tidak berdistribusi normal.

b. Uji Homogenitas adalah uji variabel dependen untuk mengetahui apakah variabel memiliki varian yang sama dalam kategori variabel independen (Ghozali, 2016). Jika terdapat lebih dari satu variabel independen, maka harus ada data homogeneity of variance di dalam cell yang dibentuk oleh variabel independen. Uji ini dinamakan dengan uji levene's test of homogeneity. Jika angka signifikan levene's test of homogeneity Sig. $>$ 0,05 maka hipotesis nol ditolak yang menyatakan grup memiliki varian yang sama dan sebaliknya, apabila hasil signifikan levene's test of homogeneity Sig. < 0,05, menunjukkan hasil probabilitas signifikansi yang memiliki arti varian tidak sama dan hal ini tidak fatal untuk ANOVA dan analisis masih dapat diteruskan sepanjang grup memiliki ukuran sampel yang sama.

\section{Uji Hipotesis}

a. Uji One-way ANOVA digunakan untuk menganalisis variabel yang berupa nilai atau angka (mumeral variabel) dengan beberapa asumsi yang mendasarinya yaitu untuk membandingkan rata-rata kelompok yang ada. Uji One-way ANOVA dengan tingkat signifikansi $\alpha=0,05$.

b. Uji Post Hoc Test digunakan untuk menguji perbedaan kinerja keuangan antar perusahaan telekomunikasi yang dilihat pada output tukey test dan Bonferoni test. output tukey test dilakukan untuk sampel yang sama sedangkan Bonferoni test untuk sampel yang berbeda.

c. Uji Homogeneous subset bertujuan untuk menguji apakah grup kinerja keuangan antara perusahaan telekomunikasi mempunyai perbedaan rata-rata yang tidak berbeda secara signifikan yang nantinya terkelompok dalam tiga subset yang berbeda. Jika tidak terdapat perbedaan yang signifikan maka ketiga sampel akan terkelompok dalam satu subset.

\section{HASIL DAN PEMBAHASAN}

\section{A. Uji Asumsi Klasik}

\section{Uji Normalitas}

Uji normalitas bertujuan untuk mengetahui apakah variabel yang digunakan berdistribusi normal atau tidak. Berdasarkan tabel diatas, menunjukkan bahwa data berdistribusi normal. Hal ini dilihat dari nilai Asym.sig lebih besar dari nilai Sig 0,05. 
Tabel. 2 Uji Homogenitas

\begin{tabular}{|c|c|c|c|c|}
\hline & Levene Statistic & df1 & df2 & Sig. \\
\hline CR & 1.545 & 2 & 27 & 0.232 \\
\hline QR & 1.807 & 2 & 27 & 0.183 \\
\hline DAR & 4.956 & 2 & 27 & 0.015 \\
\hline DER & 6.999 & 2 & 27 & 0.004 \\
\hline TAT & 1.743 & 2 & 27 & 0.194 \\
\hline NPM & 4.915 & 2 & 27 & 0.015 \\
\hline ROA & 5.569 & 2 & 27 & 0.009 \\
\hline ROE & 12.914 & 2 & 27 & 0.000 \\
\hline
\end{tabular}

Dengan demikian, data ini dapat digunakan untuk pengujian selanjutnya.

\section{Uji Homogenitas}

Uji Homogenitas bertujuan untuk menguji variabel dependen untuk mengetahui apakah variabel tersebut memiliki varian yang sama dalam setiap kategori variabel independen. Berdasarkan hasil Levene Statistic pada table diatas menunjukkan bahwa nilai $\mathrm{F}$ test untuk current ratio adalah 1.545, quick Ratio sebesar 1.807, Debt to assets ratio sebesar 4.956, Debt to equity ratio sebesar 6.999, Total assets turnover sebesar 1.743, Net profit margin sebesar 4.915, Return on assets sebesar 5.569, dan Return on equity 12.914 serta diketahui bahwa rasio current ratio, Quick Ratio, dan Total assets turnover tidak signifikan pada $0,05(\rho>0,05)$ yang berarti hipotesisi nol tidak dapat ditolak yang menyatakan variance sama, berarti asumsi ANOVA terpenuhi. Namun, hasil uji signifikansi untuk Debt to assets ratio, Debt to equity ratio, Net profit margin, Return on assets, dan Return on equity menunjukkan bahwa tingkat signifikansinya pada 0,05 $(\rho<0,05)$ yang berarti variance tidak sama (berbeda). Apabila ada data yang tidak homogeny, sepanjang grup memiliki ukuran sampel yang sama, maka tidak fatal untuk ANOVA dan analisis masih dapat diteruskan.

\section{B. Uji Hipotesis \\ 1. Uji One-Way ANOVA}

Untuk pengujian hipotesis, penelitian ini menggunakan one way ANOVA yang bertujuan untuk mengetahui perbandingan kinerja keuangan PT. Telkom, PT. Indosat dan PT. XL Axiata. Berikut hasil Uji one way ANOVA yang tampak pada tabel 3:

\section{Indikator Likuiditas}

Berdasarkan tabel 3, nilai $\mathrm{F}$ hitung Current ratio sebesar 17.101 dengan probabilitas sebesar 0.000 yang berarti $\rho<0,05$, maka ketiga kelompok sampel mempunyai rata-rata Current ratio yang berbeda (signifikan). Sedangkan nilai F hitung Quick Ratio sebesar 16.333 dengan probabilitas sebesar 0.000 yang berarti $\rho<0,05$, maka ketiga kelompok sampel mempunyai ratarata Quick Ratio yang berbeda (signifikan). Dengan demikian, hasil penelitian ini menolak hipotesisi $\mathrm{H0}$ dan mendukung hipotesis $\mathrm{Ha}$ yaitu terdapat perbedaan yang signifikan antara kinerja keuangan pada PT. Telekomunikasi Indonesia Tbk, PT. Indosat Tbk dan PT. PT.XL Axiata Tbk dilihat dari rasio likuiditas.

\section{Indikator Solvabilitas}

Berdasarkan tabel 3, nilai $\mathrm{F}$ hitung Debt to assets ratio sebesar 22.843 dengan probabilitas sebesar 0.000 yang berarti $\rho<0,05$, maka ketiga kelompok sampel mempunyai rata-rata Debt to assets ratio yang berbeda (signifikan). Sedangkan nilai F hitung Debt to equity ratio sebesar 8.185 dengan probabilitas sebesar 0.002 yang berarti $\rho<0,05$, maka ketiga kelompok sampel mempunyai rata-rata Debt to equity ratio yang berbeda (signifikan). Dengan demikian, hasil penelitian ini menolak hipotesisi $\mathrm{HO}$ dan mendukung hipotesis $\mathrm{Ha}$ yaitu terdapat perbedaan yang signifikan antara kinerja keuangan pada PT. Telekomunikasi Indonesia Tbk, PT. Indosat Tbk dan PT. PT.XL 
Tabel 3. Uji one way ANOVA

\begin{tabular}{|c|c|c|c|c|c|c|}
\hline & & $\begin{array}{c}\text { Sum of } \\
\text { Squares }\end{array}$ & df & $\begin{array}{c}\text { Mean } \\
\text { Square }\end{array}$ & $\mathbf{F}$ & Sig. \\
\hline $\mathbf{C R}$ & Between Groups & 13318.556 & 2 & 6659.278 & 17.101 & 0.000 \\
\hline & Within Groups & 10514.242 & 27 & 389.416 & & \\
\hline & Total & 23832.798 & 29 & & & \\
\hline QR & Between Groups & 12643.546 & 2 & 6321.773 & 16.333 & 0.000 \\
\hline & Within Groups & 10450.717 & 27 & 387.064 & & \\
\hline & Total & 23094.262 & 29 & & & \\
\hline DAR & Between Groups & 3019.124 & 2 & 1509.562 & 22.843 & 0.000 \\
\hline & Within Groups & 1784.273 & 27 & 66.084 & & \\
\hline & Total & 4803.397 & 29 & & & \\
\hline DER & Between Groups & 125774.981 & 2 & 62887.490 & 8.185 & 0.002 \\
\hline & Within Groups & 207456.483 & 27 & 7683.573 & & \\
\hline & Total & 333231.464 & 29 & & & \\
\hline TAT & Between Groups & 0.281 & 2 & 0.141 & 17.689 & 0.000 \\
\hline & Within Groups & 0.215 & 27 & 0.008 & & \\
\hline & Total & 0.496 & 29 & & & \\
\hline NPM & Between Groups & 2295.555 & 2 & 1147.778 & 30.518 & 0.000 \\
\hline & Within Groups & 1015.453 & 27 & 37.609 & & \\
\hline & Total & 3311.008 & 29 & & & \\
\hline ROA & Between Groups & 1056.253 & 2 & 528.127 & 46.060 & 0.000 \\
\hline & Within Groups & 309.584 & 27 & 11.466 & & \\
\hline & Total & 1365.837 & 29 & & & \\
\hline ROE & Between Groups & 3624.122 & 2 & 1812.061 & 24.281 & 0.000 \\
\hline & Within Groups & 2014.965 & 27 & 74.628 & & \\
\hline & Total & 5639.087 & 29 & & & \\
\hline
\end{tabular}

Axiata Tbk dilihat dari rasio Solvabilitas.

\section{Indikator Aktivitas}

Berdasarkan tabel 3, nilai $\mathrm{F}$ hitung Total asset turnover sebesar 17.689 dengan probabilitas sebesar 0.000 yang berarti $\rho<0,05$, maka ketiga kelompok sampel mempunyai rata-rata Total asset turnover yang berbeda (signifikan). Dengan demikian, hasil penelitian ini menolak hipotesisi $\mathrm{H} 0$ dan mendukung hipotesis Ha yaitu terdapat perbedaan yang signifikan antara kinerja keuangan pada PT. Telekomunikasi Indonesia Tbk, PT. Indosat Tbk dan PT. PT.XL Axiata Tbk dilihat dari rasio Aktivitas.

\section{Indikator Profitabilitas}

Berdasarkan tabel 3, nilai $\mathrm{F}$ hitung Net profit margin sebesar 30.518 dengan probabilitas sebesar 0.000 yang berarti $\rho<0,05$, maka ketiga kelompok sampel mempunyai rata-rata Net profit margin yang berbeda (signifikan). Nilai F hitung Return on asset sebesar 46.060 dengan probabilitas sebesar 0.000 yang berarti $\rho<0,05$, maka ketiga kelompok sampel mempunyai ratarata Return on asset yang berbeda (signifikan) serta Nilai F hitung Return on equity sebesar 24.281 dengan probabilitas sebesar 0.000 yang berarti $\rho<0,05$, maka ketiga kelompok sampel mempunyai rata-rata Return on equity yang berbeda (signifikan). Dengan demikian, hasil penelitian ini menolak hipotesisi $\mathrm{HO}$ dan mendukung hipotesis Ha yaitu terdapat perbedaan yang signifikan antara kinerja keuangan pada PT. Telekomunikasi Indonesia 
Tabel 4. Uji Post Hoc Test

\begin{tabular}{|c|c|c|c|c|c|}
\hline & \multicolumn{2}{|c|}{ Perusahaan } & \multirow{2}{*}{$\begin{array}{c}\begin{array}{c}\text { Mean } \\
\text { Difference }\end{array} \\
42.95400^{*}\end{array}$} & \multirow{2}{*}{$\begin{array}{c}\text { Std error } \\
8.82515\end{array}$} & \multirow{2}{*}{$\begin{array}{c}\text { Sig. } \\
(\mathbf{0 . 0 5 )}) \\
0.000\end{array}$} \\
\hline $\mathbf{C R}$ & Telkom & Indosat & & & \\
\hline & Telkom & XL Axiata & $46.25600 *$ & 8.82515 & 0.000 \\
\hline & Indosat & XL Axiata & 3.30200 & 8.82515 & 0.926 \\
\hline \multirow[t]{3}{*}{ QR } & Telkom & Indosat & $41.67900 *$ & 8.79845 & 0.000 \\
\hline & Telkom & XL Axiata & $45.20500^{*}$ & 8.79845 & 0.000 \\
\hline & Indosat & XL Axiata & 3.52600 & 8.79845 & 0.916 \\
\hline \multirow[t]{3}{*}{ DAR } & Telkom & Indosat & $-22.51800 *$ & 3.63550 & 0.000 \\
\hline & Telkom & XL Axiata & $-19.77800 *$ & 3.63550 & 0.000 \\
\hline & Indosat & XL Axiata & 2.74000 & 3.63550 & 0.734 \\
\hline \multirow[t]{3}{*}{ DEB } & Telkom & Indosat & $-135.47800 *$ & 39.20095 & 0.005 \\
\hline & Telkom & XL Axiata & $-139.15700 *$ & 39.20095 & 0.004 \\
\hline & Indosat & XL Axiata & -3.67900 & 39.20095 & 0.995 \\
\hline \multirow[t]{3}{*}{ TAT } & Telkom & Indosat & $0.23000 *$ & 0.03987 & 0.000 \\
\hline & Telkom & XL Axiata & $0.16500^{*}$ & 0.03987 & 0.001 \\
\hline & Indosat & XL Axiata & -0.06500 & 0.03987 & 0.250 \\
\hline \multirow[t]{3}{*}{ NPM } & Telkom & Indosat & $20.48100 *$ & 2.74260 & 0.000 \\
\hline & Telkom & XL Axiata & $15.69300^{*}$ & 2.74260 & 0.000 \\
\hline & Indosat & XL Axiata & -4.78800 & 2.74260 & 0.207 \\
\hline \multirow[t]{3}{*}{ ROA } & Telkom & Indosat & $13.87500^{*}$ & 1.51434 & 0.000 \\
\hline & Telkom & XL Axiata & $10.68600 *$ & 1.51434 & 0.000 \\
\hline & Indosat & XL Axiata & -3.18900 & 1.51434 & 0.107 \\
\hline \multirow[t]{3}{*}{ ROE } & Telkom & Indosat & $26.17200 *$ & 3.86338 & 0.000 \\
\hline & Telkom & XL Axiata & $18.55300^{*}$ & 3.86338 & 0.000 \\
\hline & Indosat & XL Axiata & -7.61900 & 3.86338 & 0.139 \\
\hline
\end{tabular}

Tbk, PT. Indosat Tbk dan PT. PT.XL Axiata Tbk dilihat dari rasio Profitabilitas.

\section{Uji Post Hoc Test}

Hasil uji post hoc test dengan indikator rasio likuiditas

Current ratio PT. Telkom dengan PT.Indosat menunjukkan bahwa terdapat perbedaan rata-rata sebesar 42.95400 dengan nilai signifikansi $0.000<0,05$ yang berarti bahwa current ratio PT. Telkom dengan PT.Indosat terdapat perbedaan yang signifikan. Current ratio PT. Telkom dengan PT.XL Axiata terdapat perbedaan rata-rata sebesar 46.25600 dengan nilai signifikansi $0.000<0,05$ yang berarti bahwa current ratio PT. Telkom dengan PT.XL Axiata terdapat perbedaan yang signifikan dan current ratio
PT. Indosat dengan PT.XL Axiata terdapat perbedaan rata-rata sebesar 3.30200 dengan nilai signifikansi $0.926>0,05$ yang berarti bahwa current ratio PT. Indosat dengan PT.XL Axiata tidak terdapat perbedaan yang signifikan.

Quick ratio PT. Telkom dengan PT.Indosat terdapat perbedaan rata-rata sebesar 41.67900 dengan nilai signifikansi $0.000<0,05$ yang berarti bahwa quick ratio PT. Telkom dengan PT.Indosat terdapat perbedaan yang signifikan. Quick ratio PT. Telkom dengan PT.XL Axiata terdapat perbedaan rata-rata sebesar 45.20500 dengan nilai signifikansi $0.000<0,05$ yang berarti bahwa quick ratio PT. Telkom dengan PT.XL Axiata terdapat perbedaan yang signifikan dan 
quick ratio $\mathrm{PT}$. Indosat dengan PT.XL Axiata terdapat perbedaan rata-rata sebesar 3.52600 dengan nilai signifikansi $0.916>0,05$ yang berarti bahwa quick ratio $\mathrm{PT}$. Indosat dengan PT.XL Axiata tidak terdapat perbedaan yang signifikan.

\section{Hasil uji post hoc test dengan indikator rasio solvabilitas}

Debt to assets ratio PT. Telkom dengan PT.Indosat terdapat perbedaan rata-rata sebesar -22.51800 dengan nilai signifikansi $0.000<0,05$ yang berarti bahwa debt to assets ratio PT. Telkom dengan PT.Indosat terdapat perbedaan yang signifikan. Debt to assets ratio PT. Telkom dengan PT.XL Axiata terdapat perbedaan rata-rata sebesar -19.77800 dengan nilai signifikansi $0.000<0,05$ yang berarti bahwa debt to assets ratio $\mathrm{PT}$. Telkom dengan PT.XL Axiata terdapat perbedaan yang signifikan dan debt to assets ratio PT. Indosat dengan PT.XL Axiata terdapat perbedaan ratarata sebesar 2.74000 dengan nilai signifikansi $0.734>0,05$ yang berarti bahwa debt to assets ratioPT. Indosat dengan PT.XL Axiata tidak terdapat perbedaan yang signifikan.

Debt to equity ratio PT. Telkom dengan PT.Indosat terdapat perbedaan rata-rata sebesar -135.47800 dengan nilai signifikansi $0.005<0,05$ yang berarti bahwa debt to equity ratio PT. Telkom dengan PT.Indosat terdapat perbedaan yang signifikan. Debt to equity ratio $\mathrm{PT}$. Telkom dengan PT.XL Axiata terdapat perbedaan rata-rata sebesar -139.15700 dengan nilai signifikansi $0.004<$ 0,05 yang berarti bahwa debt to equity ratio PT. Telkom dengan PT.XL Axiata terdapat perbedaan yang signifikan dan debt to equity ratio $\mathrm{PT}$. Indosat dengan $\mathrm{PT}$.XLAxiata terdapat perbedaan rata-rata sebesar -3.67900 dengan nilai signifikansi $0.995>0,05$ yang berarti bahwa debt to equity ratioPT. Indosat dengan PT.XL Axiata tidak terdapat perbedaan yang signifikan.

\section{Hasil uji post hoc test dengan indikator rasio aktivitas}

Total asset turnover PT. Telkom dengan PT.Indosat terdapat perbedaan ratarata sebesar 0.23000 dengan nilai signifikansi $0.000<0,05$ yang berarti bahwa total asset turnover PT. Telkom dengan PT.Indosat terdapat perbedaan yang signifikan. total asset turnover PT. Telkom dengan PT.XL Axiata terdapat perbedaan rata-rata sebesar 0.16500 dengan nilai signifikansi $0.001<0,05$ yang berarti bahwa total asset turnoverPT. Telkom dengan PT.XL Axiata terdapat perbedaan yang signifikan dan total asset turnover PT. Indosat dengan PT.XL Axiata terdapat perbedaan ratarata sebesar - 0.06500 dengan nilai signifikansi $0.250>0,05$ yang berarti bahwa debt to equity ratioPT. Indosat dengan PT.XL Axiata tidak terdapat perbedaan yang signifikan.

Hasil uji post hoc test dengan indikator rasio Profitabilitas

Net profit margin PT. Telkom dengan PT.Indosat terdapat perbedaan rata-rata sebesar 20.48100 dengan nilai signifikansi $0.000<0,05$ yang berarti bahwa net profit margin PT. Telkom dengan PT.Indosat terdapat perbedaan yang signifikan. net profit margin PT. Telkom dengan PT.XL Axiata terdapat perbedaan rata-rata sebesar 15.69300 dengan nilai signifikansi $0.000<0,05$ yang berarti bahwa net profit margin PT. Telkom dengan PT.XL Axiata terdapat perbedaan yang signifikan dan net profit margin PT. Indosat dengan PT.XL Axiata terdapat perbedaan ratarata sebesar -4.78800 dengan nilai signifikansi $0.207>0,05$ yang berarti bahwa net profit margin PT. Indosat dengan PT.XL Axiata tidak terdapat perbedaan yang signifikan.

ROA PT. Telkom dengan PT.Indosat terdapat perbedaan rata-rata sebesar 13.87500 dengan nilai signifikansi $0.000<$ 0,05 yang berarti bahwa ROA PT. Telkom dengan PT.Indosat terdapat perbedaan yang signifikan. ROA PT. Telkom dengan PT.XL Axiata terdapat perbedaan rata-rata sebesar 10.68600 dengan nilai signifikansi $0.000<$ 0,05 yang berarti bahwa ROA PT. Telkom dengan PT.XL Axiata terdapat perbedaan yang signifikan dan ROA PT. Indosat dengan PT.XL Axiata terdapat perbedaan rata-rata sebesar -3.18900 dengan nilai signifikansi $0.107>0,05$ yang berarti bahwa ROA PT. Indosat dengan PT.XL Axiata tidak terdapat perbedaan yang signifikan.

ROE PT. Telkom dengan PT.Indosat 
Tabel 4. Uji Post Hoc Test

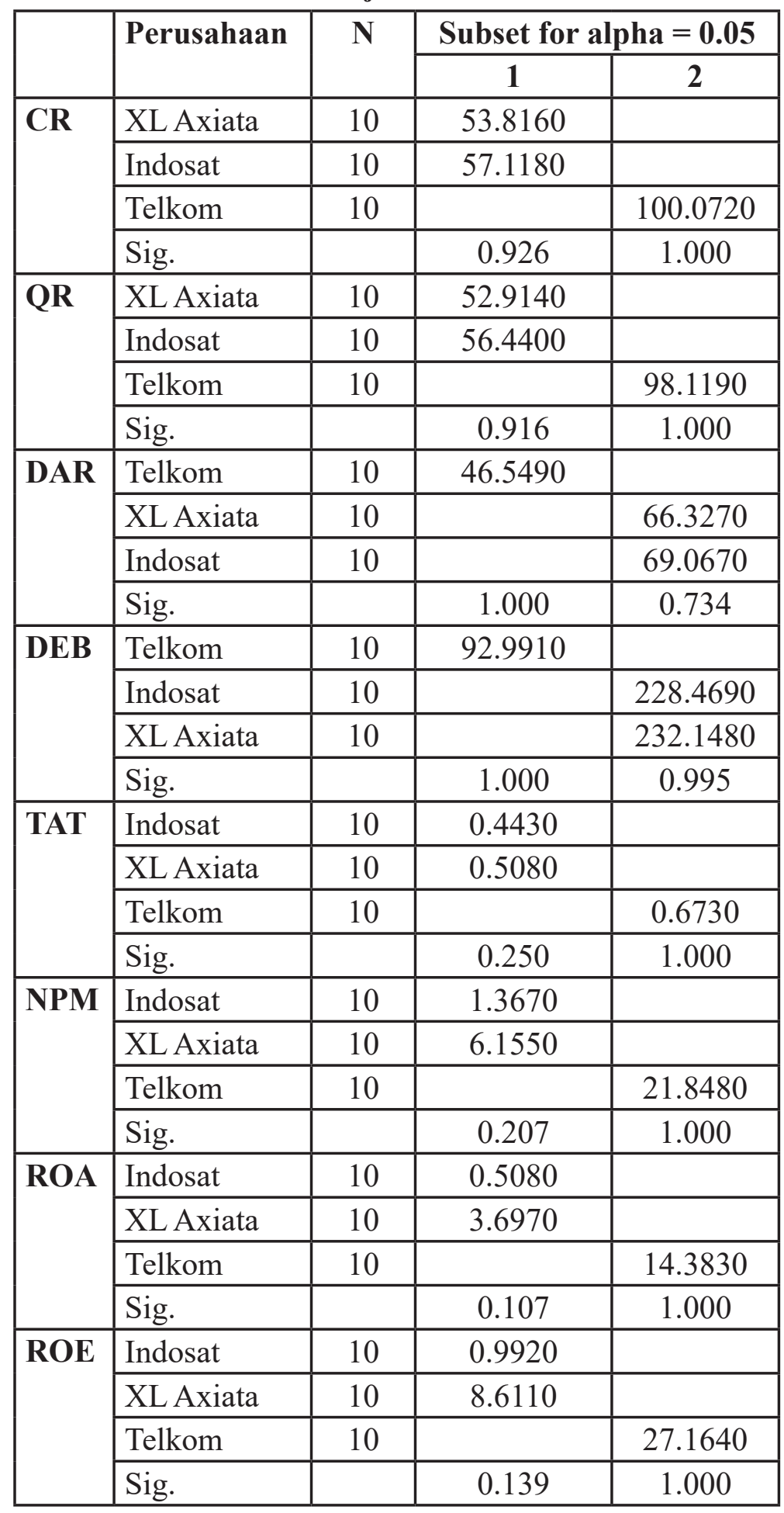

Means for groups in homogeneous subsets are displayed.

a. Uses Harmonic Mean Sample Size $=10.000$.

Sumber : data sekunder diolah, 2018

terdapat perbedaan rata-rata sebesar 26.17200 dengan nilai signifikansi $0.000<$ 0,05 yang berarti bahwa ROE PT. Telkom dengan PT.Indosat terdapat perbedaan yang signifikan. ROE PT. Telkom dengan PT.XL Axiata terdapat perbedaan rata-rata sebesar
18.55300 dengan nilai signifikansi $0.000<$ 0,05 yang berarti bahwa ROE PT. Telkom dengan PT.XL Axiata terdapat perbedaan yang signifikan dan ROE PT. Indosat dengan PT.XL Axiata terdapat perbedaan rata-rata sebesar -7.61900 dengan nilai signifikansi 
$0.139>0,05$ yang berarti bahwa ROE PT. Indosat dengan PT.XL Axiata tidak terdapat perbedaan yang signifikan.

\section{Uji Homogeneous Subset Indikator Likuiditas}

Currentratio pada tabel 5 menunjukkan nilai signifikansi 0.926 yaitu menyatakan bahwa rata-rata current ratio antara PT. XL Axiata dan PT. Indosat dalam satu subset) tidak berbeda secara statistik, sedangkan nilai ratarata current ratio $\mathrm{PT}$. Telkom berbeda dengan PT. XL Axiata dan PT. Indosat sehingga ada pada subset sendiri di kolom kedua.

Quick Ratio pada tabel 5 menunjukkan nilai signifikansi 0.916 yaitu menyatakan bahwa rata-rata Quick Ratio antara PT. XL Axiata dan PT. Indosat dalam satu subset) tidak berbeda secara statistik, sedangkan nilai ratarata Quick Ratio PT. Telkom berbeda dengan PT. XL Axiata dan PT. Indosat sehingga ada pada subset sendiri di kolom kedua.

\section{Indikator Solvabilitas}

Debt to assets ratio pada tabel 5 menunjukkan nilai signifikansi 1,000 yaitu menyatakan bahwa rata-rata Debt to assets ratio $\mathrm{PT}$. Telkom berbeda dengan $\mathrm{PT}$. XL Axiata dan PT. Indosat sehingga ada pada subset sendiri di kolom pertama, sedangkan signifikansi Debt to assets ratio sebesar 0.734 antara PT. XL Axiata dan PT. Indosat dalam satu subset di kolom kedua) tidak berbeda secara statistik.

Debt to equity ratio pada tabel 5 menunjukkan nilai signifikansi 1,000 yaitu menyatakan bahwa rata-rata Debt to equity ratio $\mathrm{PT}$. Telkom berbeda dengan $\mathrm{PT}$. XL Axiata dan PT. Indosat sehingga ada pada subset sendiri di kolom pertama, sedangkan signifikansi Debt to equity ratio sebesar 0.995 antara PT. XL Axiata dan PT. Indosat dalam satu subset di kolom kedua) tidak berbeda secara statistik.

\section{Indikator Aktivitas}

Total asset turnover pada tabel 5 menunjukkan nilai signifikansi 0.250 yaitu menyatakan bahwa rata-rata Total asset turnover antara PT. XL Axiata dan PT. Indosat dalam satu subset) tidak berbeda secara statistik, sedangkan nilai rata-rata Total asset turnover PT. Telkom berbeda dengan PT. XL Axiata dan PT. Indosat sehingga ada pada subset sendiri di kolom kedua.

\section{Indikator Profitabilitas}

NPM pada tabel 5 menunjukkan nilai signifikansi 0.207 yaitu menyatakan bahwa rata-rata NPM antara PT. XL Axiata dan PT. Indosat dalam satu subset) tidak berbeda secara statistik, sedangkan nilai rata-rata NPM PT. Telkom berbeda dengan PT. XLAxiata dan PT. Indosat sehingga ada pada subset sendiri di kolom kedua.

ROA pada tabel 5 menunjukkan nilai signifikansi 0.107 yaitu menyatakan bahwa rata-rata ROA antara PT. XL Axiata dan PT. Indosat dalam satu subset) tidak berbeda secara statistik, sedangkan nilai rata-rata ROA PT. Telkom berbeda dengan PT. XL Axiata dan PT. Indosat sehingga ada pada subset sendiri di kolom kedua.

ROE pada tabel 5 menunjukkan nilai signifikansi 0.139 yaitu menyatakan bahwa rata-rata ROE antara PT. XL Axiata dan PT. Indosat dalam satu subset) tidak berbeda secara statistik, sedangkan nilai rata-rata ROE PT. Telkom berbeda dengan PT. XL Axiata dan PT. Indosat sehingga ada pada subset sendiri di kolom kedua.

\section{KESIMPULAN}

Kesimpulan yang diperoleh dari analisis dan pembahasan data dalam penelitian ini adalah : Terdapat perbedaan yang signifikan antara kinerja keuangan pada PT. Telekomunikasi Indonesia Tbk, PT. Indosat Tbk dan PT. PT.XL Axiata Tbk dilihat dari rasio likuiditas. Hal ini dibuktikan dengan nilai F hitung Current ratio sebesar 17.101 dengan nilai sig 0.000 dan nilai F hitung Quick Ratio sebesar 16.333 dengan sig sebesar 0.000 menunjukkan bahwa nilai sig current ratio dan Quick Ratio adalah 0,000<0,05, maka ketiga kelompok sampel mempunyai rata-rata yang berbeda (signifikan).

Terdapat perbedaan yang signifikan antara kinerja keuangan pada PT. Telekomunikasi Indonesia Tbk, PT. Indosat Tbk dan PT. PT.XL Axiata Tbk dilihat dari rasio Solvabilitas. Hal ini dibuktikan dengan 
nilai $\mathrm{F}$ hitung Debt to assets ratio sebesar 22.843 dengan sig sebesar 0.000 dan nilai F hitung Debt to equity ratio sebesar 8.185 dengan sig sebesar 0.002 yang menunjukkan bahwa $\rho<0,05$, maka ketiga kelompok sampel mempunyai rata-rata DAR dan DEB yang berbeda (signifikan).

Terdapat perbedaan yang signifikan antara kinerja keuangan pada PT. Telekomunikasi Indonesia Tbk, PT. Indosat Tbk dan PT. PT.XL Axiata Tbk dilihat dari rasio Aktivitas. Hal ini dibuktikan dengan nilai $\mathrm{F}$ hitung Total asset turnover sebesar 17.689 dengan probabilitas sebesar 0.000 yang berarti $\rho<0,05$, maka ketiga kelompok sampel mempunyai rata-rata Total asset turnover yang berbeda (signifikan).

Terdapat perbedaan yang signifikan antara kinerja keuangan pada PT. Telekomunikasi Indonesia Tbk, PT. Indosat Tbk dan PT. PT.XL Axiata Tbk dilihat dari rasio Profitabilitas. Hal ini dibuktikan dengan nilai F hitung Net profit margin sebesar 30.518 dengan sig sebesar 0.000 , nilai $\mathrm{F}$ hitung Return on asset sebesar 46.060 dengan sig sebesar 0.000 dan nilai $\mathrm{F}$ hitung Return on equity sebesar 24.281 dengan sig 0.000 menunjukkan bahwa nilai sig ke tiga rasio yaitu $0.000<0,05$, maka ketiga kelompok sampel mempunyai rata-rata NPM, ROA, dan ROE yang berbeda (signifikan).

\section{SARAN}

Penelitian ini diharapkan dapat menjadi bahan evaluasi kinerja bagi masingmasing perusahaan telekomunikasi sehingga dapat memperbaiki kinerja perusahaan. PT. Indosat dan PT. XL Axiata perlu meningkatkan rasio likuiditasnya. Perusahaan perlu untuk mengelola asset lancar secara efektif dan efisien sehingga ketika perusahaan dilikuidasi, perusahaan memiliki kemampuan untuk membayar tagihan-tagihannya..selain itu, kedua perusahaan tersebut pun harus memperhatikan presentase penggunaan sumber modal dalam menunjang kegiatan operasional. Semakin banyak penggunaa modal dari luar perusahaan akan sangat beresiko bagi pemegang saham.

\section{DAFTAR PUSTAKA}

Agasta Hanny dan Budiyanto. 2012. Analisis Perbandingan Kinerja Keuangan Pada PT.Indosat,TbkdanPT.Telekomunikasi Indonesia, Tbk Yang Terdaftar Di Bursa Efek Indonesia. Jurnal Sekolah Tinggi Ilmu Ekonomi Indonesia (STIESIA) Surabaya

Fahmi Irham. 2015. Pengantar Manajemen Keuangan Teori dan Soal Jawab. Penerbit Alfabea. Bandung

Friska Kindangen Claudia. 2016. Analisis Perbandingan Kinerja Keuangan Pada Perusahaan Telekomunikasi Yang Terdaftar Di Bursa Efek Indonesia Periode 2011-2014 (Studi Kasus Pada PT. Telekomunikasi Indonesia Tbk dan PT. XL Axiata Tbk). Jurnal Berkala Ilmiah Efisiensi Volume 16 No. 03 Tahun 2016

Giri Lintang Timur Putra. 2017. Evaluasi Kinerja Keuangan Perusahaan Menggunakan Rasio Keuangan (Studi Empiris Pada Perusahaan Manufaktur yang Terdaftar Di Bursa Efek Indonesia). SKRIPSI. Fakultas Ekonomi Universitas Sanata Dharma. Yogyakarta

Ghozali, Imam. 2016. Aplikasi Analisis Multivariate deangan Program IBM SPSS 23. Badan Penerbit Universitas Diponegoro : Semarang

Hanafi, Mamduh M. dan Halim, Abdul. 2014. Analisis Laporan keuangan. Penerbit UPP STIM YKPN. Yogyakarta

Irenne Manitik Yunita. 2013. Analisis Perbandingan Kinerja Keuangan Pada PT .XL Axiata Tbk. Dan PT. Indosat Tbk. Jurnal EMBA Vol.1 No.4 Desember 2013, Hal. 1974-1982 ISSN 2303-1174

Ulum Hafidzul, Ronny Malavia Mardani dan 
Budi Wahono. 2016. Analisis Supit Yolanda. 2013. Perbandingan Kinerja Perbandingan Kinerja Keuangan Keuangan PT. Telkom Tbk dan Perusahaan Telekomunikasi Yang PT. Indosat Tbk Tahun 2006- 2011. Tercatat Di BEI (Studi kasus pada Jurnal EMBA Vol.1 No.4 Desember PT. Telekomunikasi Indonesia Tbk. 2013, Hal. 116-126 ISSN 2303-1174 dan PT. Indosat Tbk. periode 2006 - 2015). e - Jurnal Riset Manajemen Prodi Manajemen. Fakultas Ekonomi Unisma. website:www.fe.unisma.ac.id 